\title{
What's the Problem? Ackerman and Ayres on Campaign Finance Reform
}

\author{
David A. Strauss $\dagger$
}

For many people, it is obvious that there is a problem with the way political campaigns are financed in the United States. But if you ask what the problem is, you are likely to get different answers. Is it that wealthy people have too much influence? Or is the problem that politicians, in order to raise money, must cater to special-interest groups? That is a different concern; many members of interest groups are not themselves wealthy. Or is the problem just the perception of some form of improper influence, not the reality? Is the problcm that politicians spend too much time and effort on fundraising and not enough on formulating ideas and governing? Or is the problem not what the current system does to politicians or to policy but rather what it does to donors-specifically, that potential donors feel compelled to make contributions out of fear of antagonizing future officeholders? All these various potential problems are mentioned from time to time as reasons for reforming campaign finance, but it makes a difference which ones are the real problems. Different diagnoses will dictate differcnt reforms.

Bruce Ackerman and Ian Ayres have challenging and interesting ideas about how to reform campaign finance. ${ }^{1}$ Their proposal in Voting with Dollars has two main components. The first is that campaign contributions must be made anonymously. ${ }^{2}$ Contributions will be given not to campaigns directly but to a trust fund, which will then distribute the money to the campaign designated by the contributor. ${ }^{3}$ Information about who gave to

Copyright $(2003$ California Law Review, Inc. California Law Review, Inc. (CLR) is a California nonprofit corporation. CLR and the authors are solely responsible for the content of their publications.

$\dagger$ Harry N. Wyatt Professor of Law, The University of Chicago. This Review Essay originated as a comment on Bruce Ackerman's lecture at the Brennan Center Jorde Symposium, held at University of California, Berkeley School of Law (Boalt Hall) on March 10, 2002. I am grateful to the Brennan Center for its invitation, to Elizabeth Garrett, Eric Posner, and Cass Sunstein for helpful comments on an earlier draft of this review, and to the Bernard G. Sang Faculty Fund and the Elise O. and Philip Sang Faculty Fund at the University of Chicago Law School for financial support.

1. See Bruce ackerman \& lan Ayres, Voting with Dollars: A New Paradigm for Campaign Finance (2002).

2. Id. at 6 .

3. Id. ("Contributors will be barred from giving money direetly to candidates. They must instead pass their checks through a blind trust. Candidates will get access to all money deposited in their account with the blind trust.") 
the trust fund, and how much, will be concealed by secrecy requirements modeled on those governing tax returns. The point is both to prevent candidates from identifying who contributed to their campaigns and to prevent contributors from making credible representations to candidates about the amount of any contribution or even about the fact that they contributed. ${ }^{4}$

The second component of Ackerman and Ayres's proposal is a system of public funding-essentially, as they say, a voucher system. During each election cycle, every citizen will have the ability to direct an amount of public money (they propose $\$ 50$ ) from the treasury into one or more chosen campaigns. ${ }^{5}$ Citizens can also delegate this power to an intermediary group. ${ }^{6}$ But this voucher cannot legally be sold for money, any more than a vote may be sold. The result, Ackerman and Ayres plausibly say, will be a massive infusion into politics of public funds directed by individual citizens' choices. ' Ackerman and Ayres propose that these two measures be taken together: Campaigns will be funded by a combination of anonymous private donations, which are subject only to very high dollar limits, and public funds allocated by means of vouchers that are distributed equally to all voters.

Ackerman and Ayres's book has all sorts of virtues. To begin with, their ideas are bracingly ingenious. As Ackerman and Ayres point out, their proposal that contributions must be made anonymously-the "secret donation booth," as they call it-defies the all-but-universal conventional wisdom. Nearly everyone, from those most skeptical of campaign finance reform to the biggest enthusiasts, favors more disclosure; Ackerman and Ayres call for secrecy. Vouchers are, of course, popular in other arenas, but so far as I know, Ackerman was the first to propose them for campaign finance. $^{8}$

Beyond the impressive big picture, Ackerman and Ayres devote a lot of attention to the devilish details. They painstakingly describe exactly how they would deal with primary elections and various real-world problems that occur in the electoral cycle, and they show how they would try to close the inevitable loopholes. They handle the constitutional issues realistically and thoughtfully, refraining, unlike many reformers, from the outright rejection of the Supreme Court's leading decision on campaign finance, Buckley v. Valeo. ${ }^{9}$ Throughout, the book displays the deep belief in popular

4. Id.

5. Id. at $12-24$.

6. Id. at $70-71$.

7. Id. at 7

8. See Bruce Ackerman, Crediting the Voters: A New Beginning for Campaign Finance, AM. ProsPECT, Spring 1993, at 71. For similar proposals, see Edward B. Foley, Equal-Dollars-PerVoter: A Constitutional Principle of Campaign Finance, 94 CoLUM. L. REv. 1204 (1994), and Richard L. Hasen, Clipping Coupons for Democracy: An Egalitarian/Public Choice Defense of Campaign Finance Vouchers, 84 CALIF. L. REV. 1 (1996).

9. 424 U.S. 1 (1976). 
sovereignty that has been a trademark of Ackerman's work, in particular, for decades.

But what problems are they trying to solve? On this point they are a little unclear. Most of the time, they present their "secret donation booth" anonymity proposal as a way of preventing "special-interest dealing" and "influence buying"-that is, preventing politicians from rewarding contributors by making policy decisions that favor them. ${ }^{10}$ But it is not clear what constitutes a special-interest deal; it is not clear that special-interest deals are always a bad thing; and it is not clear that the Ackerman and Ayres anonymity proposal will prevent them. On the other hand, requiring anonymity does help with a problem Ackerman and Ayres do not emphasize-the problem of contributors' feeling obliged to give even if they do not want to, in order to avoid unfavorable treatment by a successful candidate.

Ackerman and Ayres's objectives in calling for vouchers are a little clearer. The idea is to provide a source of funds for campaigns (once special interests are discouraged from contributing) and to enhance public deliberation by having funding decisions made by individual citizens instead of by a statutory formula." There is no fully satisfactory way of allocating public funds to campaigns, and the Ackerman and Ayres proposal certainly deserves serious consideration. But my principal question is whether this form of citizen involvement will improve the quality of public debate, as Ackerman and Ayres claim, or will instead have thc opposite effect. And, as is always the case when large amounts of public funds are to be spent, there is a question whether the game is worth the candle.

In Part I of this Review Essay, I will consider Ackerman and Ayres's anonymity proposal. In Part I.A, I suggest that Ackerman and Ayres are probably too optimistic about the likelihood that their regime of enforced anonymity will prevent special-interest legislation. The secret ballot does not prevent such legislation; it is not clear that the "secret donation booth" will do much better. In addition, Ackerman and Ayres may underestimate the costs of concealing information about contributors. In Part I.B, I examine the assumption, made by Ackerman and Ayres (and many others), that it is generally a bad thing for politicians to reward campaign contributors. That assumption seems too simple, and again it raises the question of just what problem campaign finance reform is intended to address.

In Part I.C, I consider the possibility-suggested by Ackerman and Ayres, but not quite squarely put forward-that anonymity helps secure political equality by dampening the influence of wealthy contributors. Inequality is, in my view, a legitimate concern of campaign finance reform,

10. The authors refer repeatedly to these concerns as the justification for the anonymity proposal. See, e.g., ACKERMAN \& AYRES, supra note 1, at 6-9, 25, 30, 48, 51, 61, 65, 93, 94.

I1. Id. at 4-5, 7 . 
but it seems doubtful that the Ackerman and Ayres anonymity requirement will address it effectively. Finally, in Part 1.D, 1 suggest one problem that Ackerman and Ayres mention but perhaps do not sufficiently emphasize, and that their anonymity proposal really does help solve. That is the problem of extortion: contributions that are made not willingly but because a contributor fears retaliation.

In Part Il, I discuss the other part of the Ackerman and Ayres proposal, the voucher system for financing campaigns. In some ways this system would be clearly superior to the current system of public funding. But in other respects the voucher proposal eould actually make things worse, precisely along the dimension that Ackerman and Ayres most care about: vouchers may degrade the quality of public discourse. Finally, I consider whether, given their advantages and disadvantages, the significant public expense of a voucher program would be justified.

\section{I \\ SECRECY, SPECIAL INTERESTS, AND ExTORTION \\ A. Will the Secret Donation Booth Succeed Where the Secret Ballot Failed?}

Ackerman and Ayres's principal reason for wanting campaign contributions to be kept anonymous is to prevent politicians from being "bought." 12 If contributions are kept anonymous, really anonymous so that a candidate cannot possibly know who gave what to her campaign, then candidates will have no way of rewarding their contributors. Specialinterest deals between candidates and contributors will become impossible, and contributors will stop trying to buy influence. Ackerman and Ayres are not entirely clear in specifying the purpose of the anonymity regime; as I will discuss later, in one passage they suggest that they are quite comfortable with quid pro quo exchanges under certain circumstances. ${ }^{13}$ But most often they present the anonymity proposal as a way of preventing "specialinterest deal[s]" in which people give money in the hope that they will obtain, in return, a benefit from the candidate if she wins the election. ${ }^{14}$

Ackerman and Ayres predict that the anonymity regime will reduce the amount that people will contribute, because in the current system some contributions are motivated by the prospect of such a quid pro quo. ${ }^{15}$ But the vouchers will help make up the shortfall. In this way, Ackerman and

12. See, e.g., id. at 6 ("Just as the secret ballot makes it more difficult for candidates to buy votes, a secret donation booth makes it harder for candidates to sell access or influence."); id. at 27-28 ("A candidate is less likely to sell access or influenee if he can't be sure that the buyer has actually paid the price."); see also supra note 10.

13. See infra note 29 and accompanying text (discussing politicians' responses to Political Action Committees ("PACs")).

14. See, e.g., ACKERMAN \& AYRES, supra note 1 , at $6,25,30,48,61,65$.

15. Id. at 30-31. 
Ayres say, the voucher proposal complements the anonymity proposal. The system will be roughly as well funded and much healthier overall.

Ackerman and Ayres explicitly model their proposal for a "secret donation booth" on the secret ballot. ${ }^{16}$ The analogy is exceptionally interesting, but there is a problem: The secret ballot does not seem to prevent candidates from "selling" themselves for votes; why should the "secret donation booth" do any better? Assuming that we can coherently define what constitutes a pernicious special-interest deal between candidates and groups, no one seems to doubt that candidates pander to groups in order to obtain their votes, not just their money. To some extent, this happens because candidates can tell, in the aggregate, which groups have voted for them, even though ballots are secret: candidates rely on polling data or data from voting districts dominated by certain groups. 1t is unclear whether the Ackerman and Ayres proposal would prevent candidates from doing the same kind of thing with contributions.

Even leaving aside aggregate data, however, candidates are able to "sell" themselves for votes because the understanding between voters and candidates does not operate as a quid pro quo in the way that the Ackerman and Ayres model presupposes. Voters support a candidate because the candidate has committed to a position they like, not just because the voters can present an IOU to the candidate and demand a benefit. Candidates promise that they will support farm subsidies, or resist any reduction in social security benefits, or oppose gun control; people who will benefit from those positions then vote for the candidate, and the candidate tries to implement the position to which she was committed, thus rewarding the people who voted for her. That is how the "deal" works, and it works even though votes are cast in secret.

In the same way, contributors will give money to candidates who have promised to support positions that the contributors favor. Candidates will continue to do what potential contributors want them to do, because they know they will obtain financial support if they do-just as they get votes that way. If candidates know that they will obtain contributions by supporting tax cuts or environmental deregulation, they will support those things-some candidates will, anyway-and contributors will fund their campaigns because they want the candidates who support those things to win office. Victorious candidates will, then, usually do what they promised, because they want to maintain their credibility for future elections. Even airtight anonymity will not prevent that kind of implicit exchange.

Ackerman and Ayres suggest, for example, that the anonymity requirement will reduce "pork barrel" expenditures (and in that way help

16. Id. at 6 ("On analogy with the secret ballot, we propose the "secret donation booth."). 
defray the cost of the voucher proposal). ${ }^{17}$ But the classic form of pork-a representative's funneling government projects to her district-easily coexists with anonymity. Representatives benefit their constituencies; they get a reputation for being able to do so; and the constituents keep the representative in office because they want to keep the benefits flowing. If this kind of exchange works with anonymous voting, which it surely does, it can work with anonymous contributing, too.

Quite beyond all of that, sometimes candidates actually believe in something. The Ackerman and Ayres portrait of political candidates occasionally comes uncomfortably close to the public-choice caricature of an individual who only wants to be elected and, once in office, will do or say whatever is needed to stay there. In fairness, Ackerman and Ayres are certainly aware of the inadequacy of this conception. They of course recognize that candidates may be motivated by an ideology or a view of what the public interest requires. But sometimes the argument for the "secret donation booth" seems to be predicated on the more crude view: Candidates are for sale; the anonymity requirement will prevent them from being bought; and only when candidates realize that they cannot be bought (because no contributor can credibly identify herself as a buyer) will the candidates, for want of anything more profitable to do, pursue the public interest.

Probably there are some office seekers who are like that, but many people who enter public life do not do so just out of a lust for power. They do so because they believe in certain things, and they want to hold office so they can implement the things they believe in. They believe in (or they oppose) military spending or the reform of public education or social welfare programs. People vote for these candidates because they share their beliefs, and they will contribute money to their campaigns for the same reason. The "bargain" between contributor and candidate (if that is the right word for it) will be secured not by an exchange, implicit or explicit, but by a shared commitment to certain public policies. In these circumstances, too, anonymity will not matter. ${ }^{18}$

For all of these reasons, anonymity seems unlikely to have the dramatic effects that Ackerman and Ayres envision. Still, it would be wrong to say that it will have no effect. Ackerman and Ayres are surely right that sometimes contributions are made only because the contributor expects to

17. Id. at 171-72.

18. Ackerman and Ayres do contrast "self-interested contributions," which the anonymity requirement is intended to prevent, with "ideological gifts," which they find completely acceptable. See $i d$. at 37 "The secret donation booth tends to filter out self-interested contributions, while allowing an unimpeded flow of ideological gifts."); see also id. at 39. But Ackcrman and Ayres do not really explain when a contribution is "self-interested" and therefore bad, and when it is "ideological" and therefore good. In any event, an individual's "ideology" (in the sense of her more general beliefs about political matters) is often aligned with her matcrial self-interest. 
identify herself later and receive a benefit, and that deals of that kind will not be made if anonymity is maintained. It is not entirely clear, for reasons I discuss later, that even such explicit exchanges are always a bad thing. When they are, it may be because the contribution has in effect been extorted from the contributor, not because the contribution will have a harmful effect on public policy.

Even if such explicit exchanges are unacceptable "special-interest deals," though, the benefits of blocking them constitute only one side of the ledger. Requiring anonymity has costs, too, and if Ackerman and Ayres overestimate the benefits of compelled anonymity, as I have suggested, they may also underestimate the costs of requiring anonymity. Ackerman and Ayres do take account of the administrative costs; indeed, they show in detail just how complicated it would be to enforce secrecy about the amount of contributions. ${ }^{19}$ But there are costs to democratic selfgovernment as well. In particular, the identity of contributors provides information about a candidate or an officeholder. ${ }^{20}$ Reformers who favor greater disclosure do so in part because they envision that contributors' identities will be used as a legitimate weapon in a campaign-not to show that a candidate has been "bought," necessarily, but to show the kinds of policies a candidate favors.

Often it is hard for anyone except insiders to know the significance of various votes that legislators cast or policy decisions that executive officials make. Sometimes it is even hard to understand the significance of a piece of legislation from reading its text. But the groups most concerned about a subject will know who has helped them and who has not. A challenger in an election might have a very difficult time showing that the provisions of an intricate statute favored by the incumbent subsidize an industry. But it might be very effective, and fairly so, for the challenger to show that the group in question is among the incumbent's most enthusiastic supporters. If contributions are anonymous, opponents will be unable to use this easily understood and valuable source of information about a candidate's actions.

Ackerman and Ayers anticipate this concern about the informational value of contributions, and they respond to it by saying, surely correctly, that politicians seldom return contributions because of adverse publicity; therefore, they say, "tainted money gains more votes than it loses." ${ }^{21}$ But this argument assumes that the "tainted" money will not be given in the anonymity regime. Sometimes it will not; but sometimes, for the reasons I

19. See id. at 49-50, 99-109.

20. See Elizabeth Garrett, The William J. Brennan Lecture in Constitutional Law: The Future of Campaign Finance Reform Laws in the Courts and Congress, 27 OKLA. CITY U. L. Rev. 687 (2002) (citing sources).

21. ACKERMAN \& AYRES, supra note 1 , at 27. 
have suggested, the contributions will still be given because the contributors will know that the candidate is committed to their cause. If anonymity is enforced in those circumstances, the candidates will get the money and not have to pay the price in adverse publicity.

\section{B. Are Campaign Contributions Like Bribes?}

If, as I have suggested, Ackerman and Ayres overestimate the difference that required anonymity would make in preventing special-interest deals, the source of the difficulty may lie in the notion-often implicit and sometimes explicit in their account-that under the current system campaign contributions are little different from bribes. ${ }^{22}$ In this respect, Ackerman and Ayres, who usually break new ground, uncharacteristically have much in common with other campaign finance reformers. This ideathat the principal problem of campaign finance is "corruption"--is commonplace. ${ }^{23}$ Indeed the Supreme Court has said that preventing eorruption, understood (mostly) in this way, is the only legitimate objective of restrictions on campaign contributions. ${ }^{24}$

The idea that campaign contributions are like bribes is mistaken, 1 think, in an important way that bears directly on Ackerman and Ayres's compelled anonymity proposal. An official who is bribed has used her official position to enrich herself. The payment goes into her bank account. But campaign contributions do not enrich the candidate personally. They go to the campaign and, unlike bribes, ean be used only for one purpose: to try to gain more votes, directly or indirectly. A contributor is (and is only) enhancing a candidate's ability to get votes. Of course there may be some slippage-some contributions may be used for the candidate's personal benefit-but the people who think the current system is corrupt are not focused on that; nor are Ackerman and Ayres.

This difference between bribes and campaign contributions matters a great deal. Ackerman and Ayres's "donation booth" would work very well to prevent bribes. A person who bribes a candidate will want to be able to identify herself and demand the quid pro quo; it is hard to see how a bribe can work if the identity of the person giving the bribe is kept secret. But the same is not true of contributions because a contributor, unlike a briber, gains something even if she is anonymous: she increases her favored candidate's chances of winning the election. The contributor might also be motivated by psychic satisfaction, just as many people who contribute to

22. See, e.g., id. at 27,48 .

23. The Supreme Court's most recent opinion dealing with campaign finance legislation repeatedly emphasizes the similarity of bribes and campaign eontributions. Nixon v. Shrink Mo. Gov't Political Action Comm., 528 U.S. 377, 389-90 (2000).

24. See Fed. Election Comm'n v. Nat'l Conservative Political Action Comm., 470 U.S. 480, $496-$ 97 (1985) ("1P]reventing corruption or the appearance of corruption are the only legitimate and compelling government interests thus far identified for restrieting campaign finances."). 
charities are. A contributor therefore has a reason to give money to a candidate even if the contributor's identity is kept secret. Sometimes contributions may operate like bribes; some contributors will expect a quid pro quo and will not make a contribution unless they can get one. Ackerman and Ayres are surely right about that. But many contributors-unlike briberswill just want to help the candidate win the election and will not mind doing so anonymously, just as voters casting a secret ballot incur the costs of going to the polls and waiting in line.

For these reasons, Ackerman and Ayres, like many others, may assimilate contributions to bribes a little too easily. That is why they may overestimate the effect that anonymity will have both on contributors' willingness to support candidates and on candidates' incentives to tailor their positions in order to obtain contributions - and therefore overestimate the extent to which anonymity will prevent interest-group deals. But the point can be pressed even further. For the most part, Ackerman and Ayres's discussion seems to take it as axiomatic that, at the very least, quid pro quo exchanges of campaign contributions for official actions are always unacceptable. This is certainly a widely held view, and Ackerman and Ayres cannot be criticized for failing to defend it in a book that does so much else. But is it obvious that this view is right?

Explicit exchanges of votes for policies are not always, or obviously, unacceptable. If the leaders of a civil rights group or a gun control group or a farm lobby announced that they would urge their followers to vote for or against certain candidates depending on what the candidates promised, or on what they had delivered while in office, that would not obviously be wrong. It would certainly not constitute corruption; some might say that it is the essence of democracy. Why would it be different if a group provided not votes but campaign contributions-bearing in mind that campaign contributions are, as I said, not a means of enriching a candidate but only a means of enabling the candidate to try to get more votes?

Ackerman and Ayres mention that anonymity requirements for campaign contributions already exist in the United States, although only in connection with judicial elections. ${ }^{25}$ The limitation to judges is revealing. Judges, unlike most other public officials, are not supposed to be responsive to popular sentiment. It would be very troubling if a group threatened to withhold votes from a judicial candidate in response to a specific ruling (or maybe even in response to a pattern of rulings), so of course it would be troubling if contributions affected a judge's rulings. By contrast, it would not obviously be troubling if an executive or legislative official announced that she made a certain decision because her constituents wanted it. If it is acceptable for officials to be responsive to popular sentiment as it is expressed in votes-and it generally is, except for judges--then why should 
officials not be responsive to sentiment expressed through contributions? And if it is all right for officials to respond to contributions, then what's wrong with the quid pro quo exchanges that Ackerman and Ayres's anonymity requirement is designed to prevent?

\section{Anonymity and Equality}

One answer to that question is that everyone has only one vote, but people have different amounts of money to contribute. That is a powerful answer, but it suggests that Ackerman and Ayres's concern with quid pro quo deals misidentifies the problem. The possibility that inequality of resources might translate into political inequality is, in my view, a legitimate concern of campaign finance reform (however difficult it may be to find a solution). But this is a different problem from the concern with "deals" in which policies are exchanged for either votes or contributions.

It is important to make this distinction, which Ackerman and Ayresand they are certainly not alone in this-sometimes elide. If quid pro quo deals are a problem only because people with more resources will get unfair advantages, then the real issue is inequality, not the deals themselves. One way to see the distinction is to conduct a thought experiment: Suppose we could ensure that the distribution of wealth was equal, or equal enough (in the sense that any inequalities were justified). Would we still be concerned about "deals" in which politicians rewarded people who contributed money to their campaigns? Or would we regard such "deals," in that counterfactual world, as just democracy in action, comparable to politicians rewarding loyal voters? To the extent we would be untroubled by deals in that counterfactual scenario, then our real concern is with inequality, and we should be addressing inequality, not trying to prevent "deals."

At one place in their book, Ackerman and Ayres make this very point, but without, 1 think, realizing the extent to which it undermines their overall argument for requiring anonymity. ${ }^{26}$ Ackerman and Ayres say that they would allow citizens to give vouchers to intermediary groups-the equivalent of Political Action Committees ("PACs") —and then allow those PACs to pass on the vouchers to candidates publicly, without conforming to the anonymity regime. ${ }^{27}$ Voucher-funded PACs could then bid openly for candidates' support. Ackerman and Ayres's explanation for not requiring anonymity seems to me on target: Once equality is ensured, they say-as it is when everyone is using only vouchers-open competition by politicians for the support of interest groups is "an entirely legitimate part of the democratic enterprise." ${ }^{28}$ As Ackerman and Ayres explain:

26. Id. at $72-74$.

27. Id.

28. Id. at 74 . 
We do not generally condemn a politician when he shapes his public views to gain the support of a majority of his fellow citizens on election day. By the same token, we should not condemn him for heeding the views of citizens when they are expressed through their contributions [of vouchers to] PACs. ${ }^{29}$

In other words, deals-even explicit, quid pro quo deals between PACs and candidates - are not a problem for Ackerman and Ayres, so long as only vouchers are being exchanged; that is why anonymity is not required when PACs give vouchers. Why, then, would Ackerman and Ayres insist on anonymity for cash contributions? Because "[w]hen we make it hard for candidates to identify contributions with certainty, we make it hard for them to respond readily to the influence of the underlying inequality of private resources." 30

This argument for compelled anonymity-that it helps overcome the problem of inequality -is quite different from the argument for anonymity that Ackerman and Ayres advance throughout most of the rest of the book, which is that anonymity prevents "deals." If special-interest deals are a problem, they are a problem even if they are deals for vouchers. But when they discuss vouchers, Ackerman and Ayres-quite plausibly, in my view-emphatically reject the idea that deals are a problem, characterizing deals instead as a core aspect of the democratic process.

If inequality is the real problem, is anonymity a solution? That is, does a concern for the unequal distribution of wealth in society justify a requirement that cash contributions be made anonymously? The answer, 1 believe, is no, for two reasons. First, while groups have unequal resources, the inequality often does not reflect the underlying inequality of wealth. Many well-funded interest groups (the AARP, the NRA, and the AAA, to mention prominent examples) are composed of members most of whom are not themselves wealthy. The groups have resources because their members are numerous or intensely interested, or both. It is difficult to see why the interest in maintaining equality should restrict the ability of groups like these to make (nonanonymous) contributions, even if those contributions are part of special-interest deals.

Second, if the objective is to prevent people with great wealth from exerting disproportionate influence over candidates and elected officials, anonymity is unlikely to do the job. As I said before, even in the Ackerman and Ayres anonymity regime, implicit deals will still be possible. Wealthy individuals seem especially well positioned to benefit from those kinds of deals. If officeholders want to gain contributions from wealthy individuals by supporting policies that favor the rich, anonymity is unlikely to stop them. It will be easy for officials to determine how to benefit wealthy 
people-either directly, by tax cuts for example, or indirectly, by policies that favor groups in which well-off people are disproportionately represented. Wealthy individuals will know who is acting in their interest and will contribute accordingly. Anonymity does not seem to be a very promising solution to the problem of inequality.

\section{The Problem of Extortion}

Special-interest "deals," then, might not be a problem; even if they are, the Ackerman and Ayres approach is of limited value as a solution. Inequality is (in my view) a much more significant problem, but the anonymity regime is ill adapted to solve it. There is, however, one undoubted problem that enforced anonymity would fix. That is the problem of extortion-of individuals who do not want to make a contribution to a campaign but feel compelled to do so because they fear that, if they do not, the candidate will use her power, if she wins the election, to retaliate against them.

Ackerman and Ayres mention this problem from time to time, but they do not emphasize it. They should, because both impressionistic evidence and economic logic suggest that contributors do feel compelled to contribute sometimes; if they do, that is unquestionably a problem, and the "secret donation booth" is an excellent way of solving it. Ackerman and Ayres's analogy to the secret ballot is again revealing. The secret ballot has not stopped interest-group politics. But the secret ballot does prevent politicians and their allies from compelling people to vote for candidates not of their choice. In an open ballot, people can be threatened with various sanctions if they do not vote in a certain way; with a secret ballot, that becomes impossible. The same would be true for campaign contributions.

Describing the problem as "extortion" is misleading if it suggests that candidates deliberately threaten to use their office to harm the interests of individuals who do not make contributions. That would be a crime in any jurisdiction. More subtle forms of the phenomenon, including forms in which the candidate does nothing culpable at all, are the real concern. People may just assume - on the basis of nothing the candidate did - that if they want favorable treatment from an office-holder they must contribute to her campaign. Or people who do not want to contribute to a candidate may feel that they have to contribute because their competitors are contributing, and if the candidate prevails, she will, naturally enough, favor policies that help the people who supported her. (The competitors may feel the same way. A cartel-like agreement among competitors not to contribute would solve the problem in principle, but there are obvious practical obstacles.)

These things may happen even if the candidate does nothing to create the impression that people will suffer adverse consequences if they do not contribute, or even if the candidate assures people that there will be no 
such consequences. Indeed they may happen even if the officeholder in fact does not harm those who do not eontribute. The various influences on policy making are complex enough that people might think that contributors are being favored, or noncontributors punished, even if that is not the case. Or potential contributors may just decide that it is better to be safe than sorry, especially if they are in competition with another group or entity that is making contributions.

Extortion, in all these forms, is one problem that the "donation booth" will solve if the identity of contributors really can be kept secret. Candidates will not know who contributed and who did not, and individuals will know that candidates lack that knowledge. Potential contributors can therefore be assured that they will not suffer retaliation. Ackerman and Ayres do not take nearly enough credit for this aspect of their proposal.

One might still question whether secrecy is the best way to deal with extortion and related problems, or whether contribution limits-a more familiar form of regulation-might be better on the whole. Contribution limits, if they are effective, do not prevent extortion, but they do mitigate the problem. A potential contributor might feel obliged to give the maximum, but once she does, she is immune from pressure. The one advantage of contribution limits is that the contributor can tell the truth; in the Ackerman and Ayres regime, contributors may have to lie and say that they contributed when in fact they did not if they want to avert potential retaliation. Ackerman and Ayres recognize that their "donation booth" proposal depends, to some degree, on contributors' willingness to deceive candidates, and they argue that the deception is not so bad because it avcrts a moral wrong. ${ }^{31}$ (The wrong they have in mind seems to be "deals," but the argument applies-with more success, in my view-to extortion as well.) They also say, with somc plausibility, that over time it might bccome taboo to discuss contributions, as it is now sometimes taboo to ask a person how she voted. All of that may be true, but it is still a point in favor of contribution limits that they can reduce the extent of extortion without requiring potential contributors to make false statements about their actions.

In any event, the usefulness of the anonymity regime in preventing extortion also highlights the complementary nature of the two parts of the Ackerman and Ayres proposal. Public financing is somctimes criticized on the ground that it compcls people to give money for a purpose-funding political campaigns - for which an adequate supply of voluntary donations is available. If some citizens will pay willingly to finance campaigns, why compel taxpayers to do so against their will? But if contributions under the current system are not, in fact, voluntary - if contributors give money not because they want the candidate to win but because they fear retaliationthen the argument for public funding is much stronger. If campaign funds 
are raised by coercive means, it surely will be better to raise them through the socially approved coercive means of taxation.

The "secret donation booth" should prevent extortion. If preventing extortion produces a shortfall in private funding, then there ought to be a shortfall in private funding, and thus there is a straightforward argument for public funding, the other half of the Ackerman and Ayres proposal. In this way, there is a natural combination of the donation booth-to try to purge the system of extorted funds-and public financing, to replace those funds.

\section{Vouchers and Public Funding}

The second part of the Ackerman and Ayres proposal-a voucher system for financing campaigns--is an intriguing variation on public financing, which is perhaps the most familiar notion in the repertoire of campaign finance reform. The Ackerman and Ayres voucher proposal, although original, is a variant form of public funding: under the Ackerman and Ayres scheme, each citizen can direct $\$ 50$ from the treasury to the campaign of his or her choice. ${ }^{32}$ Current law also provides for public funding of presidential candidates, and Ackerman and Ayres occasionally say that their system is superior because it avoids putting "bureaucrats" in charge of distributing public funds. ${ }^{33}$ This is a little unfair. The current system does not leave things up to "bureaucrats" but prescribes a formula for funding the presidential candidates of the major parties and, dcpending on their performance in previous presidential elections, some minor parties. ${ }^{34}$ The Ackerman and Ayres system does not, as they occasionally suggest, substitute citizens' funding dccisions for bureaucrats' decisions; it substitutes a formula based on currently expressed desires of citizens for one based primarily on the votes citizens cast in previous elections. There are at least two questions to be asked about this, or any, proposal for public funding: first, whether it is an improvement over other systems of public financing; and second, whether the cost to the public is worth the gains.

\section{A. Will Vouchers Enhance Deliberation?}

Ackerman and Ayres explain the mostly well-known problems with the current system, and they argue, in many ways convincingly, for the superiority of their own proposal. For example, any system based on previous years' election results, as the current one is, will have a difficult time dealing with third parties. Such a system is likely to underfinance a third party that has just emerged in response to a change in public sentiment and then 
overfinance that party when public sentiment shifts again, or when the major parties co-opt the third party's agenda. ${ }^{35}$ This was, as Ackerman and Ayres point out, what happened with Ross Perot's Reform Party in the 2000 election. ${ }^{36}$

In principle it certainly seems better to have public-financing decisions reflect the current popularity of the candidates, instead of how well their parties did in an election four years ago. To that extent, the superiority of the Ackerman and Ayres voucher proposal is manifest. Ackerman and Ayres also argue, however, that their proposal is superior because it would enhance political deliberation-people would think about, and talk about, how they will spend their vouchers as well as how they will vote, and candidates would have to direct to ordinary voters all the attention and appeals that can now be concentrated on relatively few donors.

All of this scems plausible, but there may be a darker side to this aspect of the Ackerman and Ayres proposal. One feature of elections is that election day is a single, decisive moment. Nothing the voters do before they cast their ballots counts. Opinion can shift this way and that; what matters is where it comes to rest. This feature of elections structures the entire campaign. Any appeal a candidate makes must be good for the (relatively) long term. A candidate's claims or charges must withstand scrutiny over a period of at least several weeks, maybe several months. It is not good enough just to excite a short burst of enthusiasm among supporters. This point is captured, in a way, by talk about the October surprise-a lastminute action or allegation by a candidate that is made just before election day and is designed to sway voters without being subject to critical scrutiny ${ }^{37}$ The October surprise is a dirty trick, a subversion of democratic deliberation, because it is designed to provoke a hasty and ill-considered response by voters.

The biggest risk of the Ackerman and Ayres voucher proposal, I believe, is that it will give candidates an incentive to spring October surprises early and often, not just in October. In the Ackerman and Ayres scheme, a citizen's voucher contribution, once given, is (after a brief period for reconsideration) irrevocable; it is hard to see how the system could work otherwise. This means that candidates will have every reason to try to get citizens to act impulsively. If they can get millions of citizens to make contributions early in a campaign, they can then use those contributions even if the contributors' enthusiasm wanes. The candidate whose appeal emerges slowly, over time, as the voters get to know her and get to see how she responds to the campaign, will lose out financially to the candidate who

35. See, e.g., ACKERMAN \& Ayres, supra note 1, at 20.

36. Id. at 20-21.

37. For perhaps the best-known use of the term, see GARY SICK, OCTOBER SURPRISE: AMERICA'S HOSTAGES IN IRAN AND THE ELECTION OF RONALD REAGAN (1991). 
inspires immediate but short-lived enthusiasm. It is hard to see how that is a good thing for democracy.

Ackerman and Ayres's response, I think, would be that a candidate who procures contributions that donors Iater come to regret may profit financially but will lose out when voters do finally cast their votes. That may be true if the contributions are the result of a patently dishonest or demagogic tactic, although one cannot be sure of that: a well-financed campaign might be able to cover up a multitude of sins. In any event, often matters will be more subtle. Even a candidate who has no inclination to engage in abuses will have to structure her campaign to get an immediate response from a large number of citizens. Candidates will not have the option of introducing themselves to the voters, of trying gradually to broaden their support, of getting voters who initially were undecided or leaning against them to change their minds. Any candidate who proceeds that way would put herself at a financial disadvantage to a candidate who maximized short-term enthusiasm, persuaded many people to contribute, and thereby deprived her opponent of those potential contributions. Those are the incentives that the Ackerman and Ayres voucher system will create. It is certainly not obvious that a campaign that is run in such a way will provide a superior form of deliberation on important issues. The current system-for all the manifest weaknesscs that Ackerman and Ayres point out-does not create the same dangerous incentives.

The point can be put in a slightly different way, by analogy to the "money primary," another disliked feature of current campaigns. As Ackerman and Ayres note, most candidates cannot sustain their viability beyond the earliest stages of a campaign unless they ean raise a large amount of money. ${ }^{38}$ They have to begin seeking money from donors before even a single primary vote is cast, often long before. Candidates can be effectively excluded (or even effectively anointed) on the basis of how much money they raise early in the campaign.

The Ackerman and Ayres voucher proposal would, in effect, democratize the money primary. Instead of scrambling early in the campaign to raise large sums from relatively few donors, candidates would have to scramble to raise large sums from the electorate at large. But the advantages of raising large sums early would be as great, perhaps even greater, in the voucher regime. A candidate who gained a big early advantage in fundraising in the Ackerman and Ayres system would be in at least as good a position to choke off opposition as a candidate is today.

It might sound like a good idea to make the money primary more democratic in this way, but I suspect it is not. The current audience of the money primary is a limited group of sophisticated donors-individuals and groups who are likely to be relatively well informed about politics and

38. ACKERMAN \& AYRES, supra note 1, at 19, 162-64. 
campaigns and to have experience in assessing candidates' merits and forecasting their chances. ${ }^{39}$ Such an audience is less likely to be persuaded by superficially alluring but unsound appeals, much less fraudulent or demagogic ones. Such an audience is also likely to understand that a candidate whose popularity is based on such appeals is unlikely to succeed in the long run and is therefore not a good candidate to support. In the Ackerman and Ayres system, these advantages would diminish.

In other words, in both the current system and the Ackerman and Ayres system, a candidate may be able to translate a big early lead in public opinion polls into a big fundraising advantage. But in the current system, the candidate will at least be subject to the scrutiny of sophisticated donors who may know that her lead will not last. That will reduce the advantage of the early lead and correspondingly reduce the candidate's incentive to engage in tactics designed to produce short-term enthusiasm. By contrast, in the Ackerman and Ayres system, a big early lead in what might be called the voucher polls (that is, getting voters to give the candidate their vouchers early in the campaign) will be more important. That does not seem to be an improvement. And, of course, in an alternative system of public financing -one that restricted private donations but based public funds on something other than current opinion--we might avoid the money primary in all its forms, although Ackerman and Ayres could quite properly say that such a system would have other problems and may not, in practice, be capable of being implemented.

\section{B. Are Vouchers Worth the Costs?}

The final question for the Ackerman and Ayres voucher proposal, or for any system of public financing of elections, is the most basic one. Ackerman and Ayres estimate that their system will cost about $\$ 5$ billion. ${ }^{40}$ They suggest that this cost will be offset because there will be less porkbarrel and other special-interest spending. ${ }^{41}$ For reasons I have given, I am skeptical that their system will make much of a difference along those lines. But in any event, the question remains: are the costs justified?

The answer to that question, I believe, depends on how one evaluates the concerns I have raised. First, to what extent does the current system rely, not on voluntary contributions, but on contributions that people feel compelled to give? A system in which people voluntarily fund several billion dollars' worth of expressive activity, without anyone being coerced to contribute (either by extortion or by taxation), is prima facie a system

39. See id. at 163 (The "dynamic [of the money primary] gives enormous power to big givers who organize early and know what they want.").

40. Id. at 4 ("If the 100 million Americans who came to the polls in 2000 had also 'voted' with their patriot cards during the campaign, their combined contributions would have amounted to $\$ 5$ billion.").

41. Id. at 171-72. 
worth preserving, although perhaps in the end issues of inequality will be too great. But if contributions now are, in substantial part, not voluntary but in effect extorted, then the case for public financing is much stronger.

Second, how does inequality affect campaigns? Inequality might be a problem in at least one of two ways. It might be a barrier to entry, if candidates supported by less-wealthy people cannot even get their campaigns off the ground. If that is the only way that inequality is a problem, then there is no need to equalize resources among campaigns. It will be enough to provide a "floor": a minimum level of financing, so that every campaign is viable, even if some are much better endowed. The Ackerman and Ayres voucher proposal provides such a floor. AlI candidates will have access to a certain threshold amount of money, unless they are very unpopular, in which case their candidacy does not deserve to survive.

Alternatively, inequality might create what could be called a problem of swamping. Even if less well-funded campaigns are viable, a campaign with wealthier contributors might be able to overwhelm its competitors by running more advertisements, conducting more polls, and getting more voters to the polls on election day. If that is how the problem of inequality manifests itself, then the Ackerman and Ayres proposal does not seem to provide an answer. That is because Ackerman and Ayres would allow nearly unlimited cash contributions, and, as I have argued, the anonymity requirement is not likely to discourage wealthy people from making large contributions, at least not to any great degree.

Third, as Ackerman and Ayres acutely suggest, will opening the door to public financing just permit incumbents to protect themselves ${ }^{42}$ The analogy between contributions and votes may suggest a pessimistic conclusion. We insist that each person's vote be counted equally; why not, according to reformers, insist on equality in each person's power to influence an election by making a contribution? The argument is a strong one, as far as it goes. But the regime of "one person, one vote" has, notoriously, not prevented incumbents from maintaining themselves in office through gerrymanders. Insisting on equality in finance might have the same effect: we might end up with a kind of regulation that promotes equality in one sense but simultaneously makes it very difficult to unseat an incumbent. Ackerman and Ayres are aware of this problem and plausibly argue that they have overcome it, but it is a concern that must be raised about any law regulating campaign finance.

Finally, how will a system of public funding affect political deliberation? Public funding, depending on what other regulations are imposed, might increase or diminish the cxtent of public debate. It might also shape the public debate in certain ways. I have suggested that the Ackerman and Ayres proposal may have some unfavorable effects on the nature of 
election campaigns, although no doubt other systems of public financing will have their own severe drawbacks.

\section{CONCLUSION}

It is a curious feature of campaign finance reform that the cure often precedes the diagnosis; and the diagnosis, when providcd, is often a little vague. The same seems true of Voting with Dollars. Ackerman and Ayres's proposals are ingenious and thought provoking, and the book presents them with vigor and clarity. But Ackerman and Ayres are less clear about which problems they are solving. It is not obvious that special-intcrest "deals"the principal target of Ackerman and Ayres's anonymity requirementpresent a problem that can, or should, be addressed by campaign finance regulation at all. Inequality may well be a problem that needs attention, but anonymity seems an ineffective way of solving it. Extortion may also be a problem; and it probably would be solved by an anonymity requirement; but strict contribution limits would also go a long way toward limiting extortion, and Ackerman and Ayres do not emphasize extortion as a problem that needs to be solved. The target of Ackerman and Ayres's voucher proposal-incongruities in the current system of public financing-is easier to identify, and that proposal also has clear virtues as a means of promoting a degree of equality. But the voucher proposal may also present some serious hazards to the quality of public debate.

Whatever might be said about their specific proposals, however, Ackerman and Ayres have offered an original and eye-opening approach to the regulation of campaign finance. Ackerman and Ayres envision serious consideration or even adoption of their proposals; they even set out a model statute. ${ }^{43}$ Whether or not that reflects undue optimism on their part, the debate over campaign finance reform could profit from new thinking that breaks out of the ritualized criticisms and defenses of the current system. Ackerman and Ayres, with energy and verve, unquestionably provide that.

43. Id. at 181-221. 
